Application of ICT tools in communicating information and knowledge to artisanal fishermen communities in Zanzibar

Ronald Benard

Frankwell Dulle

Sokoine University of Agriculture, Tanzania

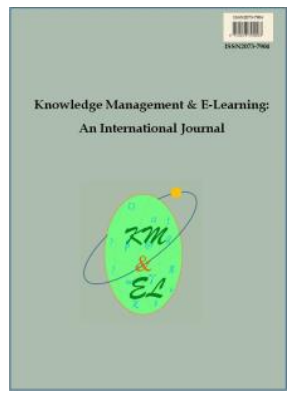

Knowledge Management \& E-Learning: An International Journal (KM\&EL) ISSN 2073-7904

Recommended citation:

Benard, R., \& Dulle, F. (2017). Application of ICT tools in communicating information and knowledge to artisanal fishermen communities in Zanzibar. Knowledge Management \& E-Learning, 9(2), 239-253. 


\title{
Application of ICT tools in communicating information and knowledge to artisanal fishermen communities in Zanzibar
}

\author{
Ronald Benard* \\ Sokoine National Agricultural Library \\ Sokoine University of Agriculture, Tanzania \\ E-mail: ronagi@yahoo.com
}

\section{Frankwell Dulle}

Sokoine National Agricultural Library

Sokoine University of Agriculture, Tanzania

E-mail: fwdulle@ suanet.ac.tz

*Corresponding author

\begin{abstract}
This article assesses the application of ICT tools in communicating information and knowledge to artisanal fishermen communities in Zanzibar. The study was carried out in four purposefully selected wards in Unguja District in Zanzibar, Tanzania. The study involved a sample size of 80 respondents. Data were collected by using document reviews, questionnaires, focus group discussions and personal observations. Results showed that artisanal fishermen need information and knowledge on weather condition, modern fish capturing methods, market and marketing, fish preservation and processing. The study also found that mobile phones and radio are the most ICTs tools used by the artisanal fishermen. The findings also revealed that communicating information and knowledge through ICT tools was limited by lack of funds, poor network connectivity, lack of training and seminars on the use of ICTs in accessing information and poor coverage on radio and television transmission. It is therefore recommended that the government should support artisanal fishermen in acquiring some of the fishing gears and ICTs tools such as GPS and sonar through subsidizing them.
\end{abstract}

Keywords: Artisan fishermen; ICT tools; Information needs; Information and knowledge communication; Zanzibar; Tanzania

Biographical notes: Ronald Benard is a Lecturer at the Sokoine University of Agriculture. His research areas include Information management, Information Management Systems, Agricultural Information and communication, Communication technology for development and Record Management.

Frankwell Dulle is an Associate Professor at the Sokoine University of Agriculture (SUA) and Research Fellow of the University of South Africa (UNISA). He holds a B.Sc. agriculture degree from SUA; Master degree in library and information studies of the University of Botswana; and a PhD (Information Science) of the University of South Africa. His research interests include: Information and Communication Technologies for education and research; Technology adoption studies; Information and communication management; and Knowledge management. 


\section{Introduction}

Tanzania is well gifted with water resources including three of the largest and most important inland lakes (Lake Victoria, Tanganyika and Nyasa) in Africa, numerous wetlands, and a diverse river system and an ocean coast-line. The country is reasonably rich in inland fishery and marine resources and therefore a significant fisheries sector (Elizabeth, 2007). Fisheries is one of the economic sub sectors of the country, which provides substantial income, employment, livelihoods, recreation, foreign earnings and revenues to the country. In 2010, the fisheries sector in Tanzania contributed $1.5 \%$ to GDP and about $10 \%$ of the national export (Planning Commission, 2012).

In Zanzibar, a fishery is basically composed of artisanal fishing units, mostly operating in inshore waters of both Unguja and Pemba Islands. In 2012, fishing industry in Zanzibar contributed $7.2 \%$ to GDP which was insignificant when compared to other sectors (Minister of State, 2015). The sector employs about 34,000 small scale fulltime fishers directly and about 4000 people are involved in other fisheries related activities such as fish processing, fish marketing, fish trade, boat building and maintenance and fishing gear mending (Ministry of Livestock and Fisheries Development, 2012).

For any activity to be achieved, adequate information and knowledge is required. Munyua (2000) viewed information and knowledge as the least expensive input for rural development. Information and knowledge is regarded as a basic and essential ingredient for bringing about social and economic change in rural areas (Morris, 2000). According to Lesaona-Tshabalala (2001), information and knowledge is a powerful tool in addressing fishery needs and if it is used appropriately, it can radically change a nation's economy. Artisanal fishermen require a variety of fishery information and knowledge in order to meet the modern day challenges of fish production, processing, marketing and distribution (Annune, Ezeani, \& Okafor, 2014). According to Uzezi (2015a), information and knowledge enables fishermen to enhance their fishing practices and yields. Despite its potential, Ozowa (1995) argued that the vital role played by scientific and technical information for agricultural and industrial development in developing countries is still neglected and accorded a lower status compared to other sectors. This view is also supported by Alam and Haque (2014) who opined that most of the farmers in rural areas still lack of information and modern agricultural knowledge.

Information and Communication Technologies (ICTs) can be defined as tools that help in processing, communication and spread of information and knowledge through electronic devices. ICT tools offer opportunity for rapid and cost effective dissemination of fishery information and knowledge to remote locations and diverse population (Kapange, 2010). ICT has given essential mechanism for disseminating knowledge and information as an input for modern fish farming (Jones \& Garforth, 1997).

Moreover, given the potentials shown by ICT tools in communicating and disseminating of fishery information and knowledge to rural and urban communities, it is not known to what level such tools have been used in communicating and disseminating of fishery information and knowledge to fishermen communities in Zanzibar and especially in Unguja Region. Therefore, the current study was set to assess the level of usage of ICTs in communicating and disseminating of fishery information and knowledge to artisanal fishermen in Zanzibar Tanzania.

\subsection{Problem statement and justification}

In fishery industry, the role of information and knowledge in enhancing fishery development cannot be underestimated. Information and knowledge is vital in increasing 
production and improving marketing and distribution strategies (Oladele, 2006). According to Mtega and Benard (2013), good information increases decision-making, enhances efficiency and provides a competitive edge. Artisanal fishermen need basic information and knowledge on their fish capture activities so as they can improve their yield. Pertiwi, Haluan, and Sari (2002) stated that for improved fish yield, artisanal fishermen require information on fish species, available resources in each catching area, fishing season, sources of credit, fish catching technologies, fish processing and storage. In essence, information is power, and when acquired, communicated and utilized can help to increase fish production rate among members in fishing communities (Ugboma, 2010). Moreover, Annune et al. (2014) reported that artisanal fishermen lack access to fishery information and knowledge that could assist them to improve their productivity. Poor accessibility of information and knowledge among the artisanal fishermen can have a negative impact in fish production rate. In this regard, the use of ICTs in accessing and communicating fishery information and knowledge to artisanal fishermen is of great importance. According to Qureshi et al. (2014), ICTs can be used to transfer information and knowledge to fishermen community and provide all the necessary fishery information about different fishing activities and upcoming events.

Despite the potential shown by ICT tools in disseminating and communicating of information and knowledge to both urban and rural dwellers, it is not known how these tools are used to facilitate communication of information and knowledge to artisanal fishermen communities in Zanzibar and specifically in Unguja District. Therefore, the current study aimed at assessing how ICTs tools can facilitate easy access and communicating of fishery information and knowledge among artisanal fishermen in Zanzibar. Specifically, the study aimed at:

- Identifying information and knowledge needed by artisanal fishermen in the study area.

- $\quad$ Ascertaining the ICTs usage level in the study area

- Determining the challenges associated with use of ICTs by artisanal fishermen

\subsection{Conceptual framework}

This study was guided by the modified Mtega and Benard (2013) conceptual framework which indicates how ICT tools are used in communicating information and knowledge to the community as outlined in Fig. 1. With reference to this study, the usage of information/knowledge depends on its perceived usefulness in fisheries and related activities.

The conceptual framework for this study links various cultural, ICT infrastructure, economic, social influence, individual, social and institutional variables necessary for the usage of rural information services. The perceived usefulness of ICT tools among fishery communities is influenced by the user's economic profiles, cultural, social, and the availability of ICTs access points. ICT infrastructure, institutional involvement and types and quality of fishery information and knowledge provided may equally have effect on the level of usage of ICT tools. Therefore, this conceptual framework guided the present study in assessing how ICT tools are used in communicating and disseminating information and knowledge to artisanal fishermen and hence improving fishery practices. 


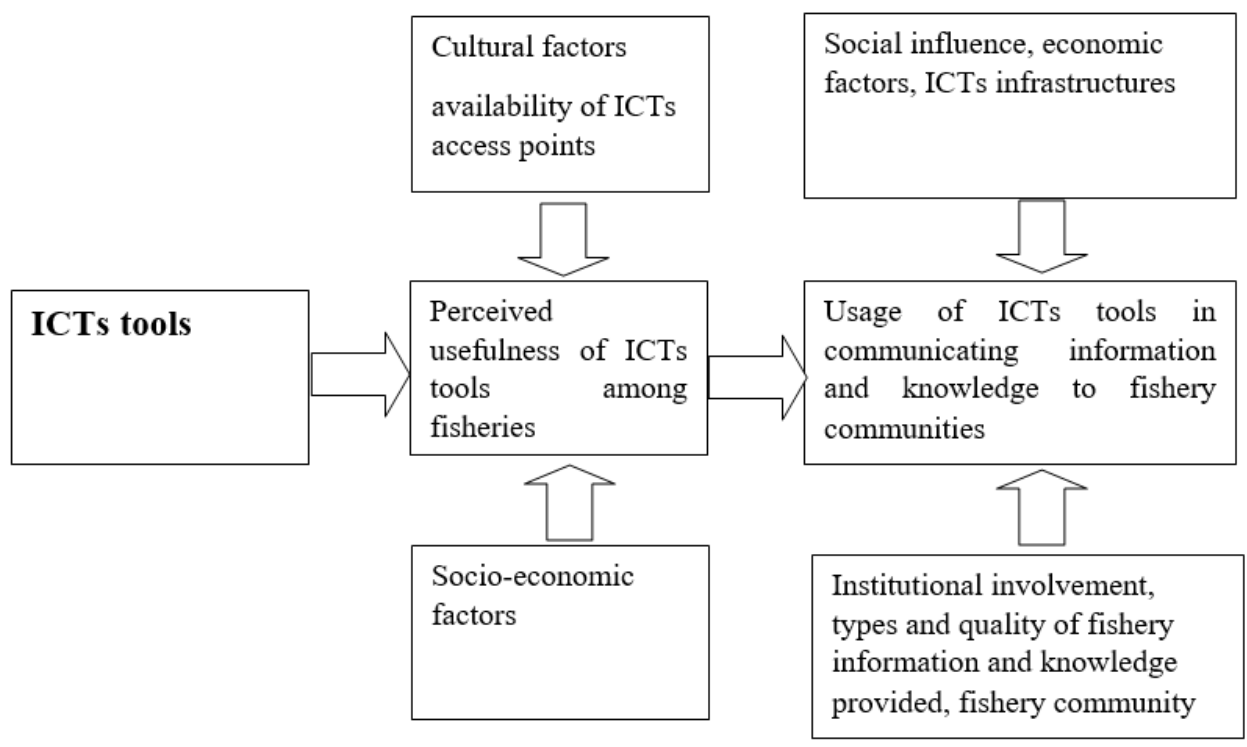

Fig. 1. The modified conceptual framework adopted from Mtega and Benard (2013)

\section{Literature review}

This section presents the reviewed literature on the study topic. The review is organized around broad themes and covers the following; knowledge and information needs of artisanal fishermen, ICTs usage by artisanal fishermen, and challenges facing artisanal fishermen in accessing fishery information and knowledge through ICTs.

\subsection{Information needs of artisanal fishermen}

Information need is an individual or group aspiration to locate and obtain information to satisfy a conscious or unconscious need (Taylor, 1962). Likewise, Devadason (1996) postulated that information need represents gaps in the current knowledge of the client. The findings by Uzezi (2015b) and Kaduskar, Nair, and Ashok (2009) revealed that the information needs of artisanal fishermen vary and range from where to get fishing gears, how to control water hyacinths, where to sell fish/fish products, how to use improved modem fishing techniques, and information about fish price in market.

\subsection{ICTs usage by artisanal fishermen}

Information and Communication Technologies (ICTs) play an important role in socio economic development of the fishermen. Several studies have been conducted on the use of ICTs by fishermen in communicating fishery information and knowledge. For instance, a study conducted by Abraham (2007) in India on the use of mobile phones in the fishing industry found that artisanal fishermen were able to discuss the price of their catches with dealers in advance via mobile phones hence accessing better price opportunities and preventing unnecessary catch wastes. In Asian countries, fishermen have improved their income as well as living standards. Through the use of GPS system, 
the artisanal fishermen have saved their time in finding locations while usage of sonar has increased their product (Walsham, 2010). Likewise, a study by Ibeun and Mdaihli (1994) on the utilization of the ICTs in Kainji area in Nigeria revealed that $56 \%$ of the fishermen had their own radio and half of respondents listened to radio at fishing area sites. About $11 \%$ of the fishermen reported to benefit from the radio programs in terms of boosting their knowledge and obtaining latest information regarding market prices. Studies conducted in Ghana by Jensen (2007) show that more than half of the $71 \%$ fishermen indicated that mobile phones helped them stay in touch with their buyers and customers; this was apart from getting fishery information from other markets.

There are no studies done to show how ICTs facilitate communicating information and knowledge among artisanal fishermen in Tanzania and particularly Zanzibar. Most of the studies that have been done in Tanzania on the use of ICTs have focused on other categories such as crop farmers, livestock keepers, students excluding artisanal fishermen. This study, therefore, intended to assess the use of ICTs by artisanal fishermen in communicating information and knowledge to fishery community and consequently improving their livelihoods.

\subsection{Challenges facing artisanal fishermen in communicating information and knowledge through ICTs}

Several challenges in communicating information and knowledge through ICTs by fishermen community have been reported. For example, Omar, Abu Hassan, Shaffril, Bolong, and D'Silva (2011) indicated that fishermen communities are facing many challenges and hindrances in ICT usage including the high costs particularly of computer and sonar. Also, a study by Hosseini, Niknami, and Chizari 2009) mentioned technophobia, lack of expertise, negative attitude about modern technology, low number of service centers in rural areas, low bandwidth, lack of hardware, and lack of appropriate infrastructure. Other cited challenges include: low number of web sites, weak telecommunication systems, old telephone lines and low quality of service provided by the service centers as the challenges which hinder fishermen communities from using ICTs (Hosseini et al., 2009). Moreover, the study by Abraham (2007) revealed that fishermen were mostly uneducated and had no proper knowledge about use of ICTs such as mobile phones and other new technologies including GPS and Sonar in sea. Likewise, Yonah (2005) mentioned that finance and lack of awareness among most of fishermen on the use of ICTs for information sharing were the main limitations constraining fishermen from ICTs usage. The negative attitude towards ICT usage is one of the problems hindering ICTs usage among fishermen (Omar et al., 2011).

\section{Research methodology}

A cross-sectional research design was used for this study. The design was chosen because it allows a researcher to collect data at once in a single point. Four wards namely Kikungwi, Kaepwani, Tindini and Uzi in Unguja region were studied. Unguja region was selected since it is among the areas in Zanzibar with high development ICTs infrastructure and fishing activities as compared to other regions.

Both random and non-random sampling techniques were used in this study. Purposive sampling method was used to select the wards and villages to be involved in the study area. According to Johnson and Christensen (2004), purposive sampling relies on the decision of the researcher focusing on some well-known criteria. The four wards 
for this study were selected purposively. These wards were selected due to the fact they were among the areas in Unguja where fishing activities were in a large scale (RGZ, 2014). From each ward, one village was selected purposively making a total of four villages. The sampling procedure required the construction of a sampling frame. Therefore, the sampling frame was constructed and it included all households involved in fisheries. The sampling frame was constructed with assistance from village government offices through Village Executive Officers (VEOs). Hence, 20 respondents were randomly chosen from each village and thus making a total sample size of 80 respondents. Singleton, Straits, and Straits (1993) argued that a sample or sub sample of 30 respondents is the bare minimum for studies in which statistical data analysis can be done.

In this study, face- to -face interviews were administered to 80 respondents. Both closed and open ended questions were included in the questionnaire. Interviews, Focus Group Discussion and personal observation were also done with some of the key informants to supplement information gathered. Four (4) key informants were involved in interviews while eight (8) participated in Focus Group Discussions. The quantitative data collected through questionnaires were coded and summarized prior to analysis by using the Statistical Product Service Solution (SPSS) version 20. The researchers' employed descriptive statistics, such as frequencies, percentages in data analysis. Qualitative data was analyzed using content analysis.

\section{Results}

This section presents the research results and the discussion of the findings. The findings presentation and discussion is based on objectives of the study.

\subsection{Background characteristics of respondents}

The results in Table 1 summarize socio-economic characteristics of the respondents. Findings show that all respondents involved in the study were males. This implies that most of the artisanal fishermen in the study area were males. This might be due to the nature of the activity as in most cases fishing is normally carried out by males. This is confirmed by the study by Okwu, Yahaya, and Obinne (2011) who also found that most the fishermen were men. Furthermore, the results reveals that about $(36.2 \%)$ of the respondents were in the 31-40 age group; $22.5 \%$ were aged between 21 - 30 years; $16.2 \%$ were aged between 41-50 years; and 11.2\% were aged between 41-60 years. This indicates that most of the respondents were in their active age. Likewise, the findings reveal that about $50 \%$ of the respondents were married, $24 \%$ of the respondents were single, $12 \%$ of the respondents were divorced and $4 \%$ of the respondents were separated. This indicates that majority of the respondents in the study area were from married couples.

Further, results show that majority of the respondents (45\%) had completed secondary education, 9.2\% reported to have never attended any school, $21.2 \%$ of respondents had primary education, and $33.8 \%$ had no formal education. This means that the respondents were moderately educated and majority could read and write that they could receive and share fisheries information through various ICTs sources.

With respect to the income levels of respondents, the results reveal that $(73.8 \%)$ respondents earned an annual income above 400,000 Tshs per annum, 8.8\% respondents had an income of less than 100,000 Tshs per annum, 7.5\% had an income ranging from 
300,001 to 400,000 Tshs per year, $6.2 \%$ respondents earned an annual income ranging from 200,001 to 300,000 Tshs per annum while $3.8 \%$ of the artisanal fishermen earned an income ranging from 100,001 to $200,000 \mathrm{Tshs}$ per annum. This indicates that majority of the respondents in the study area did not earn adequate income to meet their daily expenditures. It was for this reason fishermen reported to involve themselves in other extra economic activities including seaweeds farming which give them extra income. This can have negative impacts on usage of ICTs usage and accessibility of information/knowledge. This was supported by fisheries officer who said that fishermen with good fish harvests always made mobile phone calls asking for different fishery information and knowledge. Swanson (1997) also supports that income influence usage of some information sources among farmers.

Table 1

Socio-economic characteristics of the respondent $(\mathrm{N}=80)$

\begin{tabular}{|c|c|c|c|}
\hline Variable & Category & $\mathbf{N}$ & $\%$ \\
\hline \multirow[t]{2}{*}{ Sex } & Male & 80 & 100 \\
\hline & Female & 0 & 0 \\
\hline \multirow[t]{5}{*}{ Age (years) } & Below 20 & 11 & 13.8 \\
\hline & 21 to 30 & 18 & 22.5 \\
\hline & 31 to 40 & 29 & 36.2 \\
\hline & 41 to 50 & 13 & 16.2 \\
\hline & 51 to 60 & 9 & 11.2 \\
\hline \multirow[t]{4}{*}{ Marital status } & Single & 24 & 30.0 \\
\hline & Married & 40 & 50.0 \\
\hline & Divorced & 12 & 15.0 \\
\hline & Separated & 4 & 5.0 \\
\hline \multirow[t]{3}{*}{ Education } & No formal education & 27 & 33.8 \\
\hline & Primary education & 17 & 21.2 \\
\hline & Secondary education & 36 & 45.0 \\
\hline \multirow[t]{5}{*}{ Annual income } & Less than 100,000 & 7 & 8.8 \\
\hline & $100,001-200,000$ & 3 & 3.8 \\
\hline & $200,001-300,000$ & 5 & 6.2 \\
\hline & $300,001-400,000$ & 6 & 7.5 \\
\hline & More than 400,000 & 59 & 73.8 \\
\hline \multirow[t]{5}{*}{ Working experience(years) } & Less than 5 years & 6 & 7.5 \\
\hline & $5-10$ years & 35 & 43.8 \\
\hline & 10- 16 years & 16 & 20.0 \\
\hline & 17- 22 years & 13 & 16.2 \\
\hline & 22 years and above & 10 & 12.5 \\
\hline
\end{tabular}


Moreover, the research findings reveal that $43.8 \%$ respondents had a fishing experience of $5-10$ years, $20 \%$ respondents had an experience of 5-16 years, $16.2 \%$ had an experience of 17 - 22 years while $12.5 \%$ of the fishermen had a fishing experience of 22 years above. This signifies that artisanal fishermen in the study area had enough fishing experience on which may be shared to fellows through ICTs. To a large extent, experience affects know-how as well as the use of different extension methods including ICTs (Ani, 2006).

\subsection{Information and knowledge needs of artisanal fishermen}

The results in Table 2 summarize the information and knowledge needs of artisanal fishermen. The findings reveal that majority of artisanal fishermen $(95 \%)$ indicated that they needed information and knowledge on weather condition and modern fish capture method, 92.5\% needed information and knowledge on marketing, 91.3\% needed information on fishing gears and maintenance, fish preservation and processing. It was further revealed that $83.8 \%$ respondents needed information and knowledge on credits/loan, $66.3 \%$ fishermen needed information and knowledge on fish species, $60 \%$ needed information and knowledge on fishing rights and laws, while $52.5 \%$ needed information and knowledge on breeding seasons. Findings from interviews with fishery extension officers and FGDs reported almost similar information needs, except that they added to need information and knowledge on how to use some ICT tools such as GPS and sonar for fishing activities.

Table 2

Information and knowledge needs of artisanal fishermen

\begin{tabular}{lll}
\hline Types of information & N & \% \\
\hline Weather conditions & 76 & 95.0 \\
Information on credit/ loans & 67 & 83.8 \\
Marketing & 74 & 92.5 \\
Fish species & 53 & 66.3 \\
Breeding seasons & 42 & 52.5 \\
Fish preservation and processing & 73 & 91.3 \\
Fishing gear and maintenance & 73 & 91.3 \\
Modern fish capture method & 76 & 95.0 \\
Fisheries rights and laws & 48 & 60.0 \\
Multiple responses & & \\
\hline
\end{tabular}

\subsection{ICTs usage level in the study area by artisanal fishermen}

The findings in Table 3 indicate that the level of usage of ICTs in communicating information and knowledge to artisanal fishermen in the study area. The results show that $(82 \%)$ fishermen used mobile phones followed by those $(, 50 \%)$ who used radio sets to access information and knowledge while $82.5 \%, 78.8 \%$ and 55\% artisanal fishermen claimed to have never used sonar, internet/computer and GPS respectively in accessing/communicating information and knowledge. 
Table 3

ICTs usage level in the study area by artisanal fishermen

\begin{tabular}{lllllllll}
\hline Types of ICTs & Highly & \multicolumn{3}{c}{ Moderate } & \multicolumn{2}{c}{ Low } & \multicolumn{3}{c}{ Never used } \\
& $\mathbf{N}$ & $\mathbf{\%}$ & $\mathbf{n}$ & $\mathbf{\%}$ & & & n & \% \\
\hline Radio & 40 & 50.0 & 31 & 38.8 & 3 & 3.8 & 6 & 7.5 \\
Mobile phone & 66 & 82.5 & 8 & 10.0 & 0 & 0.0 & 6 & 7.5 \\
Television & 9 & 11.3 & 44 & 55.0 & 23 & 28.8 & 6 & 7.5 \\
Internet/computer & 0 & 0.0 & 9 & 11.3 & 63 & 78.8 & 5 & 6.3 \\
GPS & 1 & 1.3 & 27 & 33.8 & 44 & 55.0 & 8 & 10.0 \\
Sonar & 0 & 0.0 & 0 & 0.0 & 66 & 82.5 & 14 & 17.5 \\
\hline
\end{tabular}

\subsection{Challenges facing fishermen on the use of ICTs in accessing fishery information and Knowledge}

Findings on Table 4 reveal that majority of artisanal fishermen encountered problems when communicating information and knowledge through ICTs. The problems faced include lack of funds $95 \%$, poor network connectivity and lack of training and seminars on the use of ICTs in accessing information $90 \%$, poor coverage on radio and television transmission $87.5 \%$, and high cost of acquiring and maintenance ICT facilities $87.5 \%$. Other challenges experienced include lack of knowledge on how to use ICTs $86.5 \%$, lack of support from the government $72.5 \%$, and lack of awareness on the potential of ICTs for disseminating fishery information $72.5 \%$, lack of interest on listening and watching television $71.3 \%$ and language problem $58.8 \%$. It was also proved from interview and Focus Group Discussions that inappropriate time on television and radio broadcasting, irrelevance of television programmes and lack of funds as the main challenges.

Table 4

Challenges facing fishermen on the use of ICTs in accessing fishery information and Knowledge

\begin{tabular}{lll}
\hline Challenges & $\mathbf{n}$ & $\%$ \\
\hline Lack of knowledge on the use of ICTs & 69 & 86.3 \\
High cost of acquiring and maintenance ICTs facilities & 70 & 87.5 \\
Language problem & 47 & 58.8 \\
Lack of training and seminars on the use of ICTs in accessing information & 72 & 90.0 \\
Lack of funds & 76 & 95.0 \\
Poor coverage on radio and television transmission & 70 & 87.5 \\
Poor network connectivity & 72 & 90.0 \\
Lack of awareness on the use of ICTs for disseminating fishery information & 58 & 72.5 \\
Availability of electricity & 39 & 48.8 \\
Lack of interest on listening and watching television & 57 & 71.3 \\
Lack of support from the government & 58 & 72.5 \\
\hline
\end{tabular}




\section{Discussion}

This section presents a detailed discussion of the research findings of this study.

\subsection{Information and knowledge needs of artisanal fishermen}

The findings revealed that artisanal fishermen needed information and knowledge on weather condition, modern fish capturing method, market and marketing, fish preservation and processing, fishing gears and maintenance and information on credits/loan. This signifies that artisanal fishermen lack access to information and knowledge on weather condition which is very important for their fishing activities mainly in this era of climate change. However, this is not in line with findings from Okwu et al. (2011) who reported that high percent of artisanal fishermen in Nigeria had information and knowledge on weather condition. The discrepancy can be probable due to differences on economic development between the two countries. Similarly, the study revealed that most fishermen did not know where and how to use modern fish capturing methods. This implies that artisanal fishermen still relied on traditional fishing capturing methods. This was proved by observation in fishing sites as very few fishermen were using modern fish capturing methods. This is probable because of lack of information and knowledge on where and how to use them also lack of funds to purchase them. Similar findings are reported by Okwu et al. (2011) who found that majority artisanal fishermen needed information and knowledge on how and where to obtain modern fish capturing method. This information is very vital for fishermen since it enables them to improve their fishing activities and consequently raising their incomes.

Likewise, most of the artisanal fishermen complained about lack of information on marketing. This indicates that they lacked access to information on markets of their fishery products. This was confirmed by one of the fishery officer who claimed that some of the fishermen used to harvest a lot of pearls but they did not know where to sell them. These findings are in line with those of Uzezi (2015a) who recorded that majority of the artisan fishermen needed information on where to sell fish or fish products. Therefore, responsible organs should take it into consideration since it can have negative impact on fishermen's social economic development. Also, most of artisanal fishermen reported about insufficient information and knowledge on fish preservation and processing. This reveals that artisanal fishermen lack information and knowledge on how and where to store/preserve their fish/fish products. This is supported by Barguma and Ndaghu (2014) who found that one of the challenges faced by fishermen was poor knowledge on fish processing and preservation. Knowledge and information on how to process and preserve fish is very crucial to fishermen since fish is one of the perishable food which need necessary attention on its processing and storage/preservation.

Furthermore, the majority of artisanal fishermen mentioned to need information and knowledge on fishing gears and maintenance. This indicates that artisanal fishermen did not get information and knowledge on where and how to use fishing gears and on repair/maintenance. This could retard their efforts in improving fishing activities. This is agreed by Uzezi (2015b) who asserted that poor fish farming practices among fishermen account for their inability to use modern fishing gears. Moreover, the study revealed that most fishermen did not know where and how to obtain credit and loan facilities. This in line with Njoku (2004) who also found that knowing where and how to obtain credit facilities remained to be the most important need of the artisanal fishermen. This implies that artisanal fishermen did not receive any information concerning credits and loan facilities. This situation could have a negative impact on their fishery practices. 


\subsection{ICTs usage level in the study area by artisanal fishermen}

The main ICT tools used for communicating information and knowledge to artisanal fishermen were mobile phones and radio. This implies that majority of artisanal fishermen preferred using mobile phones in communicating information and knowledge regarding fishery practices. This is supported by Omar et al. (2011) who pointed out that most of the fishermen in Malaysia used mobile phones in communicating information and knowledge related to fishing activities with colleagues, agency officers and dealers in the fishing communities. This is probable because mobile phones are s more interactive and in most cases they always enhance a two-way traffic in a communication process. In such cases, fishermen can be communicating any information and knowledge to their colleagues or other information sources and acquire instant feedback. Abraham (2007) noted that fishermen are able to discuss the price of their catches with dealers in advance via cellphones hence access to better price opportunities and prevention of unnecessary catch wastes. Therefore, there is a need for the government to improve ICTs infrastructure especially in rural areas so that more fishermen can make use of mobile phones.

Likewise, it was noted that artisanal fishermen were using radio as a medium for communicating information and knowledge related to fishery activities. This signifies that fishermen were accessing information and knowledge related to fishing activities through radio listening. This supported by Qureshi et al. (2014) who recorded that radio is the mostly used ICT tools for getting the informing and knowledge about fish farming. The reason could be that radio is readily available, affordable and reaches a wide audience even in remote areas. This was observed by researcher through field observation whereby majority of fishermen had their own radio sets. Thus, radio is an effective medium for communicating and disseminating the latest fishery knowledge and information or technology to fishermen. Fishermen involved in the study mentioned radio sets to help them to gain new knowledge and improve their fishing practices.

However, results revealed that majority of the artisanal fishermen had never used sonar, internet/computer and GPS to access and communicating fishery information and knowledge. These findings differ from those of Mittal, Gandhi, and Tripathi (2009), and Teh, Teh, and Meitner (2012) who described that GPS and Sonar were the most ICT tools used by fishermen in India in obtaining the fishery information. This difference can be accounted by differences in advancement of ICT infrastructure, lack of skills, lack of awareness of the role of the Internet as an important source of fishery information, limited education and income among fishermen in the current study area. This is not surprising as for example, Malhan and Rao (2007) also reported that ICTs such as Internet, GPS and Sonar are less used in developing countries due to poor information infrastructure and the poverty level of rural communities which does not allow them to invest in ICTs. In view of this, there is a need to invest in rural ICT infrastructure and training in basic ICT skills which could enable fishermen to use such tools to access information that could improve their fishery practices and hence raising their standard of living.

\subsection{Challenges on ICTs usage}

The main problem faced by artisanal fishermen in communicating fishery information and knowledge was lack of funds. This implies that lack of funds limited fishermen from communicating information and knowledge at the study area. This was supported by one of the fishery officer during interview who mentioned to have failed to conduct seminars 
on ICTs usage to fishermen due to lack of funds. This can be the source for low usage to some of the ICT tools such as GPS and sonar because fishermen cannot afford to purchase them. Likewise, poor network connectivity was another challenge. This was confirmed during Focus Group Discussion as fishermen complained about poor internet connectivity and television signals. Also, this could be reason for low usage of internet and television. This finding is in conformity with Mtega and Malekani (2009) who mentioned poor network connectivity as the main factor hindering information accessibility among farmers in rural areas. This situation can have negative impact on information and knowledge accessibility and hence poor fishing practices which can retard fishermen socio-economic development.

Findings further revealed that lack of training and seminars on the use of ICTs in accessing information was a problem to most of the fishermen. This was proved by the researcher who observed that few fishermen possessed GPS but they complained about lack of knowledge on how to use it. This means that fishermen did not get seminars and trainings on how to use some of the ICT tools. Training is very important in order to keep fishermen update in using different ICT tools for communicating fishery knowledge. Chhachhar, Qureshi, Khushk, and Pathan (2014) opined that there is a need for capacity building through providing ICTs trainings among fishermen. Moreover, high cost of acquiring and maintenance ICT tools was also highlighted by most of the artisanal fishermen as the main constraints. For instance, during focus group discussions, some of the fishermen were complaining about high cost of purchasing GPS and Sonar, and television sets. This could contribute to low usage of such tools in the study area. Njoku (2004) noted that ICTs tools are very expensive and poor community have no access to purchase and use it. Similarly, lack of knowledge on the use of ICTs to communicate information and knowledge was another challenge. This is in agreement with Levy and Banerjee (2008) who observed that majority of the fishermen live in rural areas and most of them have no idea or knowledge on how to use ICTs for accessing information. Other constraints mentioned by majority of artisanal fishermen were lack of support from the government and lack of awareness on the use of ICTs for disseminating fishery information.

\section{Conclusion and recommendations}

From the research findings of this study, it can be concluded that artisanal fishermen need information and knowledge in order to improve their fishery practices. They need information and knowledge on weather condition, modern fish capturing method, market and marketing, fish preservation and processing, fishing gears and maintenance and information on credits/loan. This study has also demonstrated that mobile phones and radio are the most used ICT tools by the artisanal fishermen. Conversely, a number of challenges limited usage of ICT tools especially computer, GPS and the internet. Such challenges include lack of funds, poor network connectivity, lack of training and seminars on the use of ICTs in accessing information, poor coverage of radio and television transmission, high cost of acquiring and maintenance ICT tools, and lack of knowledge on the use of ICTs. However, to improve usage and access of ICT tools in the dissemination and communication of fishery information and knowledge for fishery development in the study area, the following recommendations are made:

I. The government should empower artisanal fishermen through subsidizing more modern fishing gears and ICT tools such as GPS and sonar to enable fishermen to afford and use them. 
II. Media owners should be encouraged to broadcast more fishery related programmes on both radio and television.

III. There is a need for expansion of mobile services operations to adequately cover the entire Unguja Island that fishing communities may have access to information and knowledge on fishing. Institutions or agencies involved in fisheries extension services should take advantage of the opportunity to mainstream mobile phones in extension and advisory services in the Island.

IV. Librarians should be fully involved in the direct communication and dissemination of fishery information and knowledge to artisanal fishermen as professionals.

V. The government, non-governmental organizations or institutions and related department and agencies should provide seminars and workshops on how to use ICTs and fishing gears so as to increase fishermen capacity.

VI. Local or central government authorities should liaise with librarians for instituting local community information centers/rural libraries in fishing communities nationwide. This will increase utilization of information and fish production rate.

\section{References}

Abraham, R. (2007). Mobile phones and economic development: Evidence from the fishing industry from India. Information Technologies and International Development, 4(1), 5-17.

Alam, M. K., \& Haque, A. M. (2014). Contribution of television channels in disseminating agricultural information for the agricultural development of Bangladesh: A case study. Retrieved from http://digitalcommons.unl.edu/libphilprac/1048/

Ani, A. O. (2006). Potential of oasis for sustainable agricultural production in Yobe State, Nigeria. International Journal of Agricultural and Bio-logical Sciences, 43(1), 1-5.

Annune, A. E., Ezeani, C. N., \& Okafor, V. N. (2014). Information sources dissemination and utilization patterns of the artisanal fishery sector in Benue State, Nigeria. Advances in Research, 2(12), 889-905.

Barguma, K., \& Ndaghu, A. A. (2014). Information accessibility among fish farmers in Girei, Yola North and Yola South local government areas, Adamawa State, Nigeria. ARPN Journal of Science and Technology, 4(8), 503-507.

Chhachhar, A. R., Qureshi, B., Khushk, G. M., \& Pathan, M. (2014). Problems in use of information and communication technology tools among fishermen. Journal of Applied Environmental and Biological Sciences, 4(6), 164-171.

Devadason, F. J. (1996). Practical steps for identifying information needs of clients. Paper presented at the 10th Congress of South East Asian Librarians (Cowsal X). Kuala-Lumpur, Malaysia.

Elizabeth, S. (2007). Agricultural information needs of women farmers in Mubi region, Adamawa State. Journal of Tropical Agriculture, 45(1), 69-71.

Hosseini, S. J. F., Niknami, M., \& Chizari, M. (2009). To determine the challenges in the application of ICTs by the agricultural extension services in Iran. Journal of Agricultural Extension and Rural Development, 1(1), 27-30.

Ibeun, M. O., \& Mdaihli, M. (1994). Media of communication among fishermen around Kainji lake Basin. Nigeria: New Bussa. ISBN 978-037-000-5

Jensen, R (2007). The digital provide: Information (technology), market performance, and welfare in the South Indian fisheries sector. The Quarterly Journal of Economics, 
122(3), 879-924.

Johnson, R. B., \& Christensen, L. B. (2004). Educational research: Quantitative, qualitative, and mixed approaches. Boston, MA: Allyn \& Bacon.

Jones, G. E., \& Garforth, C. (1997). The history, development, and future of agricultural extension. In B. E. Swanson, R. P. Bentz, \& A.J. Sofranko (Eds.), Improving Agricultural Extension: A Reference Manual (pp. 3-12). Rome: Food and Agricultural Organization of the United Nations.

Kaduskar, M., Nair, V., \& Ashok, A. (2009). Understanding mobile usage in rural India -'09. Retrieved from http://www.bcs.org/upload/pdf/ewic_ihci10_paper11.pdf

Kapange, B. (2010). ICTs and national agricultural research systems -The case of Tanzania. Retrieved from http://www.tzonline.org/pdf/ictsandnationalagriculturalresearchsystems.pdf

Lesaona-Tshabalala, B. V. (2001). Agricultural information needs and resources available to agriculturists and farmers in a developing country with special reference to Lesotho. Master thesis, Rand Afrikaans University, South Africa.

Levy, M. R., \& Banerjee, I. (2008). Urban entrepreneurs, ICTs, and emerging theories: A new direction for development communication. Asian Journal of Communication, 18(4), 304-317.

Malhan, I. V., \& Rao, S. (2007). Agricultural knowledge transfer in India: A study of prevailing communication channels. Library Philosophy and Practice. Retrieved from http://www.webpages.uidaho.edu/ mbolin/malhan-rao.pdf

Ministry of Livestock and Fisheries Development. (2012). Endorsement of the management plan for the Tanzanian artisanal fishery for small and medium pelagic species. the United Republic of Tanzania, Dar es Salaam.

Minister of State. (2015). Zanzibar research Agenda: 2015-2020. Second Vice President's Office, United Republic of Tanzania. Retrieved from http://www.costech.or.tz/wp-content/uploads/2015/03/Zanzibar-research-agenda1.pdf

Mittal, S., Gandhi, S., \& Tripathi, G. (2009). Impact on small farmers and fishermen through use of mobiles in India. In Proceedings of EAAE-IAAE seminar on small farms. University of Kent, UK.

Morris, C. (2000). The role of computers and information technology in rural agricultural information system. Retrieved from http://www.hs.unp.ac.za/im/morris2.pdf

Mtega, W. P., \& Malekani, A. W. (2009). Analyzing the usage patterns and challenges of telecenters among rural communities: Experience from four selected telecenters in Tanzania. International Journal of Education and Development using ICT, 5(2), 6887.

Mtega, W. P., \& Benard, R. (2013). The state of rural Information and communication services in Tanzania: A meta-Analysis. International Journal of Information and Communication Technology Research, 3(2), 64-73.

Munyua, H. (2000). Information and communication technologies (ICTS) for rural development and food scarcity: Lesson from field experience in developing countries. Paper presented at a workshop on the role of information and communication technologies in rural development and food security.

Njoku, I. F. (2004). The information needs and information-seeking behaviour of fishermen in Lagos State, Nigeria. International Information \& Library Review, 36(4), 297-307.

Okwu, O. J., Yahaya, M. A., \& Obinne, C. P. O. (2011). Analysis of artisanal fisher folk information needs and accessibility in Benue State, Nigeria. Asian Journal of Agricultural Sciences, 3(5), 408-413.

Oladele, O. I. (2006). Multilinguality of farm broadcast and agricultural information access in Nigeria. Nordic Journal of African Studies, 15(2), 199-205. 
Omar, S. Z., Abu Hassan, M., Shaffril, H. A. M, Bolong, J., \& D’Silva, J. L. (2011). Information and communication technology for fisheries industry development in Malaysia. African Journal of Agricultural Research, 6(17), 4166-4176.

Ozowa, V. N. (1995). Information needs of small scale farmers in Africa: The Nigerian example. Consultative Group on International Agricultural Research (CGIAR) News, 4(3), 10-12.

Pertiwi, S., Haluan, J., \& Sari, E. Y. (2002). Construction of marine resource database for empowering small scale fishermen. In Proceedings of the 3rd Asian Conference for Information Technology in Agriculture. Beijing, China.

Planning Commission. (2012). The Tanzania long-term perspective plan (LTPP ): The roadmap to a middle income Country. President's Office, United Republic of Tanzania. Retrieved from http://www.tzdpg.or.tz/fileadmin/documents/dpg_internal/dpg_main/DPG_Main_201 2/LTPP_2012-03-19_PRINT.pdf

Qureshi, B., Pathan, M., Chandio, F. A., Keerio, A., Buriro, R. A., \& Chhachhar, A. R. (2014). Adoption of information communication technology tools among fishermen. Journal of American Science, 10(7), 155-161.

Singleton, R. A., Straits, B. C., \& Straits, M. M. (1993). Approaches to social research. New York: Oxford University Press.

Taylor, R. S. (1962). The process of asking questions. Journal of the Association for Information Science and Technology, 13(4), 391-396.

Teh, L. C. L., Teh, L. S. L., \& Meitner, M. J. (2012). Preferred resource spaces and fisher flexibility: Implications for spatial management of small-scale fisheries. Human Ecology, 40(2), 213-226.

The Revolutionary Government of Zanzibar (RGZ). (2014). Zanzibar fisheries policy (First draft prepared with the support of SmartFish). Retrieved from http://www.tzdpg.or.tz/fileadmin/documents/dpg internal/dpg working groups_clust ers/cluster_1/agriculture/2. Ag_policies and_strategies/Zanzibar_Ag_policies/3. 201 4_Zanzibar_Fisheries_Policy_first_draft_-_18_June_2014_.pdf

Ugboma, M. U. (2010). Access to agriculture information by farmers in Niger Delta region of Nigeria, Delta State. Library Philosophy and Practice. Retrieved from http://digitalcommons.unl.edu/cgi/viewcontent.cgi?article $=1443 \&$ context=libphilprac

Uzezi, O. P. (2015a). Agricultural and information needs and utilization among migrant fishermen by gender: A study of Isoko reverie community, Delta State, Nigeria. Journal of Emerging Trends in Computing and Information Sciences, 6(5), 263-267.

Uzezi, O. P. (2015b). Information needs and seeking behavior of migrant fishermen: A case of Isoko riverine communities Delta State, Nigeria. International Journal of Scientific \& Technology Research, 4(8), 284-288.

Walsham, G. (2010). ICTS for the broader development of India: An analysis of the literature. The Electronic Journal of Information Systems in Developing Countries, 41(4), 1-20.

Yonah, Z. (2005). ICTs as tools for poverty reduction. In Proceedings of the Discourse on Engineering Contributions to the Reduction of Poverty. 